\title{
Farewell to Anarchy: The Myth of International Anarchy and Birth of Anarcophilia in International Relations
}

\author{
Paul-Erik Korvela, University of Jyväskylä
}

\begin{abstract}
This article scrutinizes the conceptual history of international anarchy. The argument purported here is that even though the idea of international anarchy is often seen as very central for the academic discipline of international relations, the concept is in fact not found from the forerunners or classics of the discipline. The assumption of international anarchy is commonly seen as a defining feature of a Realist school of international relations. Yet, the concept and especially its "Realist" implications are not to be found in the classics of Realism, from Thucydides, Machiavelli or Hobbes. The idea of "international anarchy" emerges quite tentatively during the First World War, in the writings of theoreticians like Dickinson and Spiller. But even then it does not carry the neo-Realist overtones of international anarchy as permanent condition of international relations. It is only in the 1980's that the discipline starts to huddle around this concept.
\end{abstract}

Keywords: international anarchy, political theory, Realism, conceptual history, international relations

\section{Introduction}

The discipline of international relations (IR) huddles to a large extent around the concept of international anarchy. It is by no means unambiguous what exactly is referred to with the term international anarchy as it can mean several things (Milner, 1991; Holmes, 2011; Donnelly, 2015). In general it re- 
fers to the idea that there is no superior authority above the sovereign states, which therefore are in a state of anarchy or lawless state of nature among themselves. States are considered the main actors and portrayed as powerhungry machines aiming for unchecked aggrandizement regardless of morality, norms or agreements. The "logic of anarchy" forces states to warlike behaviour and pre-emptive strikes in order to better take care of their own security. There is no organizing principle, excluding the logic of anarchy deriving from structural conditions in an arena without sovereign power greater than that of the states.

The idea is central to the discipline and it is found in basically every textbook and introduction to the study of international politics. More specifically, it is seen as deriving from the assumed classics of the discipline, especially those early writers like Thucydides, Machiavelli and Hobbes that are considered the forerunners of the Realist school of IR. In this article, the hypothesis is that there is no conception of "international anarchy" found in the writings of those aforementioned classics. The assumption of international anarchy was not central to the early Realists like Morgenthau either. The article argues that as there is no textual evidence for this conception in the alleged tradition of Realism, we must conclude that it arose as a central concept no earlier than in the 1980's and is associated with the debates within the discipline more than any changes in the actual international system. When it was needed in contemporary debates, it was read also backwards into the works of earlier writers where it is actually not to be found. Scholars like Hedley Bull who were among the founders of the so-called English School of international relations, with its focus on history and theory, paid attention to the concept already earlier but their aim was to establish that the presumed anarchy of international sphere is not incompatible with society. In other words, they argued that international anarchy is not really an anarchy, and consequently they do not assume that it would be the defining feature of the international system in the same sense as neo-Realists do. Bull has an article on anarchy already in 1966 and Martin Wight included a chapter on international anarchy in his "Power Politics", which was first published in 1946 (Bull, 1966; Wight, 1946/1978).

The article also contains some methodological points regarding the way studies of international politics are conducted. It might not be erroneous to claim that for a long time there has been a "non-debate" between political theory and international relations. The findings of one discipline do not easily find their way to the other. International relations scholars are sometimes surprisingly ignorant of the classics they are using and political theorists often dismiss questions within the confines of international politics, which they considered for a long time the mere "untidy fringe of political theory". The history of political thought has been largely ignored in IR, and this ahistoricism partly 24 
explains why much of IR scholarship is often ignored by other social sciences (see Bell, 2001: 116). Despite the advances and debates in the methodology of political thought, the scholars of IR "went on quoting Hobbes and Thucydides as if, stripped of their context, they could unproblematically speak to our current concerns" (ibid.: 117). Many of the classics of IR are more or less misread because they did not have an understanding of international relations to begin with and if one wants to read them from "IR viewpoint", it is a misreading or an anachronistic reading from the start. Martin Wight (1966) was amazed by the fact that there is no speculation about the relations between states to the same extent that there is speculation about political life within a community. In particular, there are no classics in the field of international relations prior to the nineteenth century. In contrast to the 2500 years of political theory, there is no international theory of more than 200 years. Hence the backward readings of classics from the viewpoint of IR tend to provide those classics with something they did not have. The concept of international anarchy is a good example of this anachronistic reading.

Not only is IR often insensitive to political theory, but it is also relatively insensitive to language and concepts used. The role of language has been overlooked in international relations and when one peruses the academic studies of IR, it is indeed "as if much of twentieth-century social theory and philosophy had never been written" (Bell, 2002: 327). The aim of this article is simple enough: to highlight one misreading of classics of political theory that is of crucial importance for contemporary theorizing of international relations. The article purports the argument that international anarchy, so dear in textbook presentation of "Realism" and its forerunners, is for the most part a myth. Anarchy as a "state of nature between states" is nowhere to be found in the writings of the early classics like Thucydides, Machiavelli or Hobbes. Noteworthy is the fact that not even Morgenthau has any reference to anarchy in his famous six principles of political realism in Politics Among Nations (1948). For some reason, international anarchy has been seen as constitutive feature of Realism, which is clearly a misreading. When we look at the conceptual history of international anarchy, both semasiology and onomasiology, we find that the first mentions of the term surface during the First World War, around 1916. Not even then does it carry the overtone of all-encompassing feature of the states-system that the neo-Realist and their critics have attributed to the term.

Donnelly (2015) has done excellent work in showing that anarchy was not a central concept in the early stages of the discipline, in the late 19th and early 20th centuries. It can not be constitutive for the discipline's self-understanding, as the first generation of IR scholars paid almost no attention to it. The aim of this article is to show that international anarchy was not central even for the so-called classics of Realism, where it is thought to originate. 


\section{The Myth of International Anarchy as Part of Realist Tradition}

The standard interpretation sees various Realists from Thucydides through Machiavelli and Hobbes to Morgenthau and Mearsheimer as highlighting the "essential anarchy of international system" (Kissane, 2014: 12). This often cherished assumption regarding international anarchy found in those classics should be questioned. The whole idea of presenting the historiography of the discipline as "great tradition" of Realism and subsequent great debates, as chronological succession of nonpareil authors cumulatively contributing to a conventional pattern of thought, provides a quintessential example of misreading the whole disciplinary history where analytical retrospective tradition is confused with genuine historical tradition (Schmidt, 1998: 27). International relations scholars have constructed a nebulous tradition of "Realism" without actually elucidating its historical basis because their aim has been either to validate or oppose contemporary neo-Realism rather than to understand the history of international relations and its developments (ibid.: 28-29). The result has been the elevation of certain theorists as tutelary heroes of "classical tradition" of IR and the uncritical acceptance of their alleged paradigm, which makes the study of IR revolve around state sovereignty and international anarchy (ibid.: 30).

International anarchy has been so central to modern theorizing of international relations that some scholars have even spoken of "anarchophilia" in IR (Buzan \& Little, 1994: 236). Anarchophilia is a result of ahistoric and eurocentric approach, which produces the image that the structure of international politics has always been anarchic, that this is somehow natural, and in some sense a good thing (Watson, 1997: 3). The unnecessary focus on anarchy has received criticism (e.g. Ashley 1988; Milner, 1991) and also disciplinary histories have paid attention to the "discourse of anarchy" as an odd vortex that seems to suck much of modern theory towards it, while scholars of earlier generations were not so obsessed about the concept (Schmidt, 1998; Donnelly, 2015). The aim of this article is also to scrutinize where, when and why does the discourse of international anarchy emerge. Why certain concepts receive suddenly a lot of attention is itself a question worthy of attention, as Onuf (1991) has noted regarding the concept of sovereignty.

As we learn from the entry on "Anarchie" in the Geschichtliche Grundbegriffe (Meier \& Ludz, 1972), the word itself can be traced back to antiquity, in the adjective form perhaps to the times of Homer. The reference, however, was not "international anarchy". The term denoted simply the absence of leader, especially in military affairs. The Romans did not use the word but opted for terms like seditio, tumultus or perturbatio. Anarchy is not included in the six-partite classification of regimes in Aristotle and therefore it was not 
used by those medieval authors like Thomas Aquinas and Marsilius of Padua who followed in his footsteps. Even Martin Luther's writings are bereft of any discussion of anarchy (ibid.). The Greek word re-emerges tentatively in the early modern context but it does not contain the dimension of international anarchy. Noteworthy is the fact that international anarchy has no connection whatsoever to anarchism, which emerges in the 18th century. Nobody designed the international system as allegedly anarchic, so the ideas or ideology of anarchism have not contributed to its anarchiness.

\section{Thucydides}

The standard (neorealist) IR interpretation of Thucydides as a "realist" is misleading (see Garst, 1989). Much has been made out of his Melian dialogue, and the adage that the strong take what they want and the weak suffer what they must. Yet, the whole Peloponnesian War commences with the breaking of a treaty according to Thucydides. Hence, he resorts to legal standards when explaining the reasons for war (Behr, 2010: 27). Moreover, with his reproach for the behaviour of the Athenians for their lack of considerations of justice and injustice (as exemplified in the Melian dialogue), he "critically juxtaposes factual moral disorder, which both caused war and increased during the war, with normative idea of 'good order" (ibid., 34). No traces of "anarchy" are found, let alone its glorification. Instead, in normal conditions between city-states law prevails and treaties regulate the conduct.

Although the ancient Greeks considered non-Greeks as barbarians and would not enter into agreements with them, they developed an elaborate system of religiolegal ties among the Greek city-states: the multitude and variety of inter-Greek treaties amounted to a system that would not appear in the international sphere until the nineteenth century (Nussbaum, 1958: 5-6). The extent of treaty-making among the Greek city-states can be best described as "remarkable" (Bederman, 2001: 154). The Greek system included, for instance, an element of impartial arbitration of disputes (Nussbaum, 1958: 7). Plato has Socrates say that war should be limited to fights with the barbarians whereas inter-Greek fights were only discords (ibid.: 9). We should not overestimate these Greek developmets, however, because they were largely religious practices and expressions of racial and cultural unity (ibid.). But they surely reveal that the relations between Greek city-states were not in a state of anarchy.

At the same time, however, we may note that Thucydides explains that the Spartans are "compelled" to violate the treaty because of a shift in balance of power (Forde, 1992: 374). Therefore he alludes to the idea of harsh necessities of international politics that demand immorality. Yet, balance of power is 
not proof of anarchy and we must also note that according to Thucydides the Spartans have scruples after starting the war ("they thought all their misfortunes had deservedly befallen them for that cause", 7.18). Thucydides too has been read through modern lenses, purposefully in order to show the seeds of Realism in his writings.

It is intriguing why the image of international anarchy has emerged, why it has persisted, and why it has been read into the theories of earlier classics of political theory. In order to show that this kind of backward reading of anarchy is not limited to early classics only, we can here refer to the case of Morgenthau. His "realism" too is largely bereft of anarchy, even though the mainstream (neo-)realism has hailed it as one of Morgenthau's central ideas. Behr (2010: 212-13) points to the interpretations of Robert Jervis and Robert Keohane who see anarchy as a central concept of Morgenthau's theory, while in reality the term appears only thrice in Politics Among Nations and always in a critical disassociation. The term anarchy as empirical feature of international politics is nowhere to be found in Morgenthau, nor is it among his theoretical six principles of Realism (ibid.: 213).

\section{Machiavelli}

The conventional IR interpretation has forced some political theorists, like for instance Machiavelli, into a realm where they do not belong. He has been given a special place in which to act, the realm of realpolitik, but this is not the sphere where we should put him into use, as R. B. J. Walker (1993) has argued. Walker's analysis of Machiavelli emphasises one crucial point: to the extent that Machiavelli was concerned with international relations and military affairs it is as a consequence of his account of the possibilities of political life within states (ibid.: 36). Even though Machiavelli's theories make little sense unless read in the context of the classical account of life within a political community, in IR he has been associated primarily with the theories of the relations between states. Machiavelli has been forced to the realm of realpolitik, not the community in which peace and progress are possible, but the supposed home of naked power politics, the so-called international anarchy (ibid.: 41). He has been pushed into the realm of "relations" rather than of "politics", of barbarians, of others who are understood to be beyond the limits of our political community, our political identity, our peace, justice and good government (ibid.: 42). But he himself did not make that distinction.

Many attributes of Machiavelli the Realist are missing from his actual writings. He does not employ the term reason of state (ragione di stato), even though he has been made the spiritual father of the concept in the Christian 
reception of his works and also in modern works like that of Meinecke (1924). Even though already in the 18th century commentators argued that Machiavelli's political theory is concentrated around interest ("Interest is the key word of this political system. It is the vortex of Descartes, the gravitation of Newton", Fredrick II of Prussia: Anti-Machiavel, XV), Machiavelli never employs the terminology of interests. The effect of revising Machiavelli's vocabulary in this way has been to supply him with a range of beliefs about a number of topics on which he never wrote (Skinner, 1988: 255). Anarchy, to add one more concept, is also missing from his writings.

Even though Machiavelli certainly more than hints to the fact that there is no tribunal to which to appeal in the relations between rulers and that they to an extent create their own morality, there is no reason to assume that he meant those relations to be in a state of anarchy understood as disorder and total absence of power. The IR image of Machiavelli as the Realist and advocate of power politics is biased, as it is often based only on his Il Principe. With the construction of the "scientific" Machiavelli, the objective and analytical observer of politics, his more normative and passionate writings are easily dismissed. Hartmut Behr (2010: 111) has argued that Machiavelli's picture of international order would indeed strongly resemble that what is nowadays discussed under the rubric of "regional security complexes", and that "no convincing arguments exists, however, for seizing Machiavelli as a 'realist', who would argue in favour of power politics". Behr continues by lambasting the image of Machiavelli as a thinker "who would furthermore base his analysis and international outlook on assumptions of 'anarchy' and a intrasigent promotion of 'national interest'" (ibid.). On the contrary, Machiavelli emerges as a thinker who perceives no dualism between domestic and international orders. Hence, according to Behr (ibid.: 112), the IR image of Machiavelli as the realist seems to be another misreading where the inside/outside-dualism in postnineteenth century inter-national theory gets projected to earlier eras through an a-historical, ontological lens.

Another dimension in the misreading of Machiavelli in regard to anarchy is his allegedly sinister view of the human nature, as the causes of anarchy are assumed to reside in human psyche seething with lust for power and domination. Indeed, if we assume that he held a view according to which the human nature is inherently bad, this would actually set him apart from the ancient authors like Thucydides (and thus would not set him in the "great tradition" of realists from antiquity onwards). The conception of men as naturally inclined to evil is unknown in classical antiquity. It is a product of Late Antiquity and Christianity, with its doctrine of original sin (Qviller, 1996). Yet Machiavelli's comments in this regard have been read purposefully exaggerating them. When he says that the prince can not remain good among so many who are not good, this does not mean that he would have to be bad all the time. In 
this passage, Machiavelli means that the prince needs to know when not to be good. But if possible, the prince should remain good. His political anthropology is not that all men are bad all the time, but that the wise prince must prepare for the option that not all men remain good all the time. In fact, he says that men rarely succeed in being altogether bad even if they try (Discorsi I/27). Especially in IR readings but also in the interpretations of Machiavelli's political theory in general, there is a tendency to accentuate the leonine qualities and brute force required of Machiavellian states and leaders, even though he himself clearly also points to the need of foxy qualities like shrewdness, because nothing can be achieved with mere force (Lukes, 2001).

Although the whole picture of Machiavelli as an advocate of naked power politics is in this way skewed, especially the assumption of anarchy disregards the fact that he does not employ that term. He does not make the distinction between domestic and foreign politics in the same sense as modern commentators, and he never used terms like "international sphere". His classification and cycle of regimes in Discorsi (I/2) derives from the anakyklosis of Polybius and includes the idea that popular government easily turns into what Machiavelli calls licentious ("il Popolare sanza difficultà in licenzioso si converte"). Although the idea may come in some sense close to anarchy as lawlessness and disorder, it is not the "international anarchy" and he definitely does not project similar terms to describe the international sphere. As he lacked the term, there is no mention of anarchy in his writings. The abovementioned licentious state in the circulation of governments may be the closest he comes to describing the idea of anarchy without using the term.

Machiavelli's view of conflicts sets him apart from the tradition of ancient and medieval theorists, because he sees value in internal discords. In his analyses, the conflicts between the people and the aristocracy (sometimes molti and poci, or "due umori") made states like Rome prosper. It is noteworthy, however, that seeing some positive value in conflicts separates Machiavelli not only from the ancient and medieval authors, but also from modern political theory which is often based on neutralizing of conflicts (Geuna, 2005: 20). However, despite the various conceptualizations of conflicts in Machiavelli's writings which range from tumulti, dissensione, controversie, differenzie, romori, civili discordie, fazione to sette - there is no description of anarchy especially as a condition pertaining to the relations between sovereign states. In fact, and most importantly, he did not have the concept of sovereign state to begin with and consequently he can not be thought to posit an "anarchy" between them. International anarchy is a consequence of state sovereignty, and Machiavelli did not have the latter concept either.

Machiavelli's use of lo stato is actually curious. Hexter (1957) has noted that in Il Principe the word occurs in close connection with verbs acquistare, tenere, mantenere, togliere and perdere. These verbs (to acquire, to hold, to maintain, to 30 
take away, to lose) signify that lo stato is an object, not a subject. Whereas today we speak of the state as acquiring territory, holding prisoners, maintaining a legal position, taking away property and losing a possession, Machiavelli never employs the term in such meanings. In those very rare instances where lo stato seems to be active, Machiavelli somehow stresses its anemic activity, since the only occurrence of the term with a violent verb like ribellarsi is when Machiavelli tells us about a stato that did not rebel. But in his usage it is perfectly relevant, for example, to pose the question that for us seems odd: whether or not a prince has enough state, i.e. enough standing? For Machiavelli, lo stato meant primarily command over men, as is clear from the opening words of Il Principe. Therefore, if somebody loses his control over men, he loses his stato. If he is in the process of doing so, it might be relevant to ask whether he has enough state. (Hexter, 1957: 119, 122) But states are not active independent units that could have an "anarchy" between them. Machiavelli does not have a concept of sovereign state, nor could he posit a state of anarchy between them. Although here one must resort to arguments ex nihilo, arguing that something is not to be found in Machiavelli's writings, the burden of proof is actually on those who claim that he should be read as some sort of theorist of anarchy between states.

\section{Hobbes}

It is only rather recently that authors like Michael Williams (1996), Noel Malcolm (2004: 432-56) and David Armitage (2006) have drawn our attention to the obvious misreadings of Hobbes in IR-theories. The standard way of reading Hobbes asserts that for Hobbes, the interaction between states is a state of nature and the state itself is little more than Hobbesian man writ large. The reference to "Hobbesian anarchy" prevailing in the international sphere passes as general currency although the analogy between the original Hobbesian state of nature and international anarchy does not really work, as already Hedley Bull (1966: 40-8) noted. Anarchy between sovereign states is clearly tolerable to a degree to which among individuals it is not (ibid.: 45). States are also not vulnerable in the same sense that individuals are: hence the same fears do not prevail. States also enjoy a degree of self-sufficiency that the individual lacks. Hobbes had very little to say about international relations, much less than IR scholars would like him to have said, and only became known as a theorist of international anarchy after the view of international sphere as anarchic had evolved (Armitage, 2006: 220, 231). That discourse of anarchy is a product of nineteenth and early twentieth century developments internal to the emerging disciplines of political science and international law (ibid.: 231) and was not really a concern for Hobbes himself. As Armitage (ibid.: 233) points out: "If 
the Hobbesian theory of international relations rests on a conception of international anarchy characterised by interstate competition without any possibility of cooperation, then Hobbes himself was no Hobbesian".

And if Hobbes really would have considered the relations between states as anarchical or in a state of nature then one must ask why did he not aim to end this with the same solution as the anarchy within a community: if Hobbesian individuals can make a social contract in order to escape the demise of the state of nature, then why are states not capable of ending the international anarchy in the same way (Williams, 1996: 214)? Conversely, if states-as-individuals can not contract globally between them because of suspicion and calculation, then a doubt must be cast upon the original social contract between individuals too (ibid.: 225). His "failure" to extend his argument to global Leviathan provides a clue to the fact that he did not consider international relations as taking place in a state of nature. International relations between states are anarchic in the sense that an overarching power is lacking, but that does not mean that they would be in a state of nature. Furthermore, as already Hedley Bull noted, the "Realist" assumptions associated with Hobbes are nowhere to be found in his texts: there is no glorification of war nor naked power politics, no relentless pursuit of state interest and power as an end in itself, nor the view that anything is permissible in the international realm (ibid.).

Unlike Machiavelli, Hobbes had the word. In the Leviathan (1651), Hobbes uses the term "anarchy" three times. Even from this scarce quantity alone, we could infer that the idea was not very central to him. He conjures up the term when discussing typologies of government and regards it as a bad form of democracy (in chapters XIX and XLVI). The third mention of the word connects it to "condition of mere nature":

That the condition of mere nature, that is to say, of absolute liberty, such as is theirs, that neither are sovereigns, nor subjects, is anarchy, and the condition of war: that the precepts, by which men are guided to avoid that condition, are the laws of nature: that a commonwealth, without sovereign power, is but a word without substance, and cannot stand: that subjects owe to sovereigns, simple obedience, in all things wherein their obedience is not repugnant to the laws of God, I have sufficiently proved, in that which I have already written. (chapter XXXI)

We may note that here Hobbes clearly says that laws of nature guide men to avoid anarchy. Furthermore, it is analogous to a word without substance, since a commonwealth without sovereign "cannot stand" according to Hobbes. Nowhere in the book is the assumed international anarchy found. When he speaks about anarchy, it is always with a reference to anarchy within a community, not between them. Rather than somehow seeing anarchy as taking place, Hobbes argues that laws of nature inhibit it within a community. Also 
in Behemot, the references to anarchy are connected to anarchy within a community, as in "reduced the government into anarchy". Hobbes, as is commonly known, translated "The Peloponnesian War" by Thucydides into English. In the translation, the word occurs two times, but not in the sense of international anarchy.

Now, of course he could have been talking about the concept without mentioning the word. In the dedication of De Cive, he puts forth the famous analogy of homo homini lupus, "Man to Man is an arrant Wolfe". Here, he specifically connects this idea not with relations between individuals, but between cities: "Good men must defend themselves by taking to them for a Sanctuary the two daughters of War, Deceipt and Violence: that is in plaine termes a meer brutall Rapacity". Yet this does not convince that he was talking about any sort of anarchy. A doubt could also be cast upon his zoological knowledge, since wolves are not particularly violent or deceitful (let alone warlike or in a state of anarchy) towards each other and wolf packs remain rather territorial. The fact that Hobbes makes this small reference to the rapacity and warlike condition between cities only in a dedication of his book (but not really discuss it anywhere else) is ample evidence that he did not consider it a central feature of his theory. It is certainly plausible to assume that he would have elaborated on the idea if he would have regarded it as the fulcrum of his theory. That it is only a sloppy remark in a dedication, puts its alleged centrality to his theory into question and thus also casts doubt on the whole idea of a Hobbesian anarchy in IR. Here it should perhaps be noted that it is not only the IR readings of Hobbes that are misleading in this way. Also for example Nozick commences his famous "Anarchy, State and Utopia" (1974) by alluding to a "most pessimistically described Hobbesian state of nature" (ibid.: 5) of which he nevertheless gives no reference in the works of Hobbes.

In the XIII chapter of Leviathan, Hobbes speaks about the state of nature and its theoretical war of every man against every man. He denies that this condition has ever existed between men. Instead he hints that this is the condition between sovereigns towards each other, but as soon as it has left his pen he kind of repudiates this claim:

But though there had never been any time, wherein particular men were in a condition of warre one against another; yet in all times, Kings, and persons of Soveraigne authority, because of their Independency, are in continuall jealousies, and in the state and posture of Gladiators; having their weapons pointing, and their eyes fixed on one another; that is, their Forts, Garrisons, and Guns upon the Frontiers of their Kingdomes; and continuall Spyes upon their neighbours; which is a posture of War. But because they uphold thereby, the Industry of their Subjects; there does not follow from it, that misery, which accompanies the Liberty of particular men (Leviathan, chapter XIII) 
He goes on to describe that in such a condition there is nothing unjust, no right or wrong. But that this is merely a thought experiment is clear enough. Thus the aim of Hobbes is to show why the state of anarchy does not exist. May it also be added that Hobbes's analogies are again faltering, since gladiators were not in a state of anarchy, but there were rules (and rulers) controlling their meeting at the arena and in general the whole staging of the spectacles served many important societal functions (see Kyle, 2001). Despite his penchant for precision and almost mathematical models, the state of nature in the theory of Hobbes remains an elusive concept which he updated and elaborated differently throughout his career in order to remind his readers of the consequences of disobedience (Evriginis, 2014). His inspiration for the rhetorical figure of state of nature which serves as a kind of counter-concept of political community came from different sources, like from the Biblical depiction of the Fall of Man and the ensuing original sin, and from the "savage" life of the American Indians.

In fact there are two different anarchies in IR that claim a Hobbesian pedigree. The (neo)Realist caricature of power-hungry states that do no find incentives to ameliorate the bellum omnium contra omnes, and the English School variant that actually treats the international sphere as anarchical society and insists that from the absence of overarching power does not follow the permanent state of nature (Christov, 2015: 19-20). But neither the neo-Realist "discourse of anarchy" nor the English school "Hobbesian anarchy" is found from his texts: Hobbes has been used as a theoretical linchpin and the anarchy label is attached to him as shorthand for an entire paradigm he did not really discuss himself (Ibid.: 20). Even though the idea surfaces here and there in his writings, its aim is to show what would be the alternative of the present order. Thus his aim is not to offer it as a description of the prevailing state of affairs. In IR his theoretical concept has been turned into empirical description and it has been elevated to relations between states even though he himself never made that extension. For Hobbes, states are not power-hungry machines equipped with unchecked aggression as the neo-Realist reading portrays them: the international order in his view emerges "as fundamentally ameliorative inits nature and concerned with the progress and improvement of the entire interstate domain, were states are not the only actors, and, accordingly, the analogy with natural persons, while essential, remains imperfect" (Ibid.: 128).

\section{Anarchy is what misreading classics makes of it}

The above discussion should be enough to cast a doubt on the accuracy of the international anarchy allegedly found in "classics of realism". As to anarchy, we should also keep in mind that it is mainly a purely theoretical con- 
cept that does not exist in reality. Hedley Bull, in his "The Anarchical Society" (1977/2002), argues that the correct description of international sphere is order, not disorder. Indeed, Bull argues that order is a ubiquitous quality of international politics that can be present to a larger or smaller degree, but it is never totally absent (Bull, 2002: xxxii). The lack of executive authority to enforce international law and the lack of effective sanctions against the violators have misled many into thinking that states do not comply to international law. On the contrary, nations do generally observe laws and obligations (Henkin, 1968: 45). Indeed, "international relations are less anarchical than international law, with its emphasis on sovereign equality and non-interference of states in each others' affairs, would suppose" (Müllerson, 2000: 91). The discrepancy between legal equality and practical ineaquality of sovereign states creates problems for both international law and international relations (ibid.), but the assumption of anarchy derives precisely from this sovereign equality that has in reality never existed.

Also in those assumed realist versions of international anarchy, order is not totally devoid and the glorification of naked power politics is hard to find. In general, we tend to assume too much of anarchy, as already Wendt (1992: 401-402) noted: especially the neo-Realist assumptions of self-help systems, security dilemmas and stag hunts can only emerge in interaction, and are therefore not constitutive features of anarchy but institutions created by states in interaction. In fact, no classical "realist" assumed that much anarchy and the sloppy depictions of "Machiavellian power politics" or "Hobbesian international anarchy" should be questioned as there is no textual evidence for those views in their writings.

Indeed, if one wanted to trace the genealogy of "international anarchy" understood as radical equality among sovereign states which recognize no superior authority, one would find its roots not from the "Realists" like Machiavelli and Hobbes but from the "Rationalists" (or Grotians), to borrow Martin Wight's (1991) typology of three traditions. The international anarchy is the logical extreme of Grotianism and its idea of mutually sovereign states, as Schuman (1969: 69) has noted:

If carried to its logical extreme, it would result in a situation which can only be described as international anarchy. With the breakdown of the authority of Pope and Emperor, each State pursued its own ends in disregard of the interests of others, redressing its wrongs by self-help, acting as prosecutor, judge, jury, and sheriff combined, and hotly resenting any suggestion of allegiance or responsibility to any superior power. Here, indeed, was a precivil state of nature as Hobbes had described it, in which life was "solitary, poor, nasty, brutish, and short"- in which might makes right - in which power is to the strongest and the devil takes the hindmost. Yet law may restrain the lawless. 
The idea of anarchy between sovereign states derives from this source, not from "Realism". States as sovereign and free from outside control is the basis of international law, but previous writers like Machiavelli did not conceptualize the "international sphere" in this way, even though for example Wight (1991: 15-24) argues that Realists since Machiavelli emphasize in international relations the element of anarchy.

Since there is no "international anarchy" to be found in the classics of "realism", we must ask where, then, does the idea originate. If we look at the first occurances of the twin concept (international anarchy), we can be sure that the term is in use in G. Lowes Dickinson's two books, "The European Anarchy" (1916) and "The International Anarchy 1904-1914" (1926). In these two texts Dickinson frequently uses the term international anarchy and sees it as the source of conflict in Europe and in the world. The names notwithstanding, there is no actual depiction of international anarchy to be found in these books. Dickinson's book "The International Anarchy 1904-1914" is meant as a contribution to the analysis of the causes of war. His general argument in the book is as follows:

My thesis is, that whenever and wherever the anarchy of armed States exists, war does become inevitable. That was the condition in ancient Greece, in Republican Rome, in Medieval Italy, and in Europe for several centuries after its emergence from the feudal chaos. That chaos also involved war. But such war is not properly to be called either civil or international; and with that particular condition we are not now concerned. International war, in our own age as in others referred to, is a clash between sovereign armed States. It arises in consequence of the international anarchy. (Dickinson, 1937[1926]: ix)

For Dickinson, international anarchy means the armament of sovereign states against the potential threat of others, from which war ensues. He analyses different institutions of international politics, like balance of power and diplomacy, and considers factors like national honour and public opinion manipulated by the press as catalysts of war. Yet, a detailed analysis of "anarchy" is lacking. One might note that the balance of power is normally considered as an institution that at least partly prevents wars, rather than being only the cause of war. Secondly, the workings of institutions like diplomacy clearly show that the actions in the international sphere are not anarchic or chaotic. Even if one would adopt an extremely cynical view of diplomacy as mere debauchery, intrigue and breaking of treaties, one would have to admit that it is somewhat more orderly than pure anarchy. The breaking of treaties presupposes the existence of treaties and the existence of treaties means that pure anarchy does not prevail. And if the occasional breaking of treaties would lead to the conclusion that anarchy prevails, this would mean that it prevails also 
within a community because also national legislation is violated thousands of times per day. In fact, international law is in some sense more respected than national legislations, although the popular image of international law includes the idea that it can be violated and is violated whenever states find it in their interest. Also individuals can and occasionally will violate legislation when they find it in their interest, but from that does not follow total lawlessness or anarchy.

Dickinson's conclusions in the book are that some sort of world government and disarmament of sovereign states are required to prevent war. However, he fails to see that the then prevailing situation where war occasionally breaks is not anarchic. War as institution of international politics has been and is also regulated and there are rules, norms and legislation for the conduct of war. Contrary to the popular opinion, the outbreak of war does not imply total anarchy and suspension of all rules. Dickinson's depiction is also conceptually curious: he says that anarchy prevailed in Europe for many centuries after the feudal chaos. Here a doubt could be cast on his knowledge of feudalism, since chaos is not the word usually used to describe the orderly and hierarchical feudal Europe. But in his view "anarchy" of armed states followed after "chaos". May it be noted that the origins of Westphalian system are not in the comingtogether of previously isolated communities but in the disintegration of a single community, the Western Christendom (Bull, 1966: 37).

In his "European Anarchy", Dickinson elaborates more his rather sinister view of international anarchy. The very opening words of the book address the issue and are worth quoting here at length. Here, also the usual suspects (Machiavelli and Hobbes) are named and international politics reduced to Machiavellianism:

In the great and tragic history of Europe there is a turning-point that marks the defeat of the ideal of a world-order and the definite acceptance of international anarchy. That turning-point is the emergence of the sovereign State at the end of the fifteenth century. And it is symbolical of all that was to follow that at that point stands, looking down the vista of the centuries, the brilliant and sinister figure of Machiavelli. From that date onwards international policy has meant Machiavellianism. Sometimes the masters of the craft, like Catherine de Medici or Napoleon, have avowed it; sometimes, like Frederick the Great, they have disclaimed it. But always they have practised it. They could not, indeed, practise anything else. For it is as true of an aggregation of States as of an aggregation of individuals that, whatever moral sentiments may prevail, if there is no common law and no common force the best intentions will be defeated by lack of confidence and security. Mutual fear and mutual suspicion, aggression masquerading as defence and defence masquerading as aggression, will be the protagonists in the bloody drama; and there will be, what Hobbes truly asserted to be the essence of such a situation, a chronic state of war, open or veiled. For peace itself will be a latent war; and the more the States arm to 
prevent a conflict the more certainly will it be provoked, since to one or another it will always seem a better chance to have it now than to have it on worse conditions later. Some one State at any moment may be the immediate offender; but the main and permanent offence is common to all States. It is the anarchy which they are all responsible for perpetuating. (Dickinson, 1916: introduction)

According to Dickinson, this drama will continue until empire is achieved or common law and common authority established by agreement (ibid.). $\mathrm{He}$ seems to uphold a conception of anarchy reminiscent of neo-Realist structural anarchy, where there might be changes in the units but the texture or framework of international relations does not change: "One thing only does not change, the fundamental anarchy. International relations, it is agreed, can only turn upon force. It is the disposition and grouping of the forces alone that can or does vary". Dickinson associates international anarchy strongly with Machiavellianism:

Machiavellianism is the common heritage of Europe. It is the translation into idea of the fact of international anarchy. Germans have been more candid and brutal than others in their expression and application of it, but statesmen, politicians, publicists, and historians in every nation accept it, under a thicker or thinner veil of plausible sophisms. It is everywhere the iron hand within the silken glove. It is the great European tradition.

His conclusions are that no specific nation, like the Germans, is to blame for the war and there is no specific wickedness in any state, as the real culprit of the demise is the European anarchy. Dickinsons work is important from the viewpoint of this article since it is probably the first text that connects the idea of international anarchy to the works of Machiavelli and Hobbes. Dickinson, however, was not a "Realist" and he did not offer international anarchy as a theory of international politics, let alone as the justification of power politics. He was of liberal persuasion and saw this anarchy as the cause of demise in international politics.

Paul Reinsch, whose "World Politics at the End of The Nineteenth Century" (1900) is considered the first academic study of international relations proper, does not use the concept of international anarchy. He refers to Machiavelli's conception of power politics and sees it in as the source of national imperialism:

This extreme doctrine of the state as the ultimate aim of existence recognizes no mutual duties among the various states. On the contrary, according to that view, hostile nations face each other with the vicious cruelty and cunning of wild beasts. Force rules, manipulated by art and craft. (Reinsch, 1900: 17) 
Unlike Dickinson, Reinsch sees this equilibrium of mutual sovereign states as desirable. He acknowledges that political world unity is uninviting and not desirable, because it would lead to "deadening uniformity" (ibid.: 24).

Far preferable is the present state of international equilibrium, with the intense rivalry among peoples that brings out their strongest characteristics. Even with its occasional discords, the present general harmony of the concert of nations is to be preferred to the dead monotone of a world state. ... The rivalry among nations is sharp, and calls for the constant exercise of all their intellectual, moral, and physical powers, in order to avoid the decadence that would lose them their position in the family of nations. So fierce does this struggle at times become that to men of pessimistic mood a great world warfare seems inevitable within the near future. We should, however, avoid the temper of mind that constantly engenders suspicions and exaggerated fears. Thus far, happily, no nation has acquired enough preponderance to threaten really and effectively the political existence of its neighbors. Most of the mutual fear and mistrust that mar the harmony of nations is founded on misunderstanding. (ibid.: 24-5)

Writing before the Great War, Reinsch does not, unlike Dickinson, see the absence of world government leading to anarchy but to an equilibrium. He argues that conflicts of interest may surely arise, but "to interpret these as deliberate wars of extermination is to attribute to the whole human race a viciousness that actually exists only among the worst criminal classes" (Reinsch, 1900: 70). The idea of international anarchy is nevertheless missing from Reinsch's book. It is not used as theoretical concept nor is it used to describe empirical phenomena of international politics.

The term international anarchy first emerges during the First World War, in writings of Dickinson and Gustav Spiller, who in 1916 published an article in which he juxtaposed international law and international anarchy (Spiller, 1916). Spiller argued that mere law without some authority to oversee its compliance and deliver punishments is empty and only quarantees the continuation of international anarchy (ibid.). Empirically the First World War seems to have provided water for the mills of theorists and created the atmosphere of anarchic interanational relations between sovereign states. Later, the establishment of the League of Nations in the early 1920's is a reaction to this and a step towards ending the assumed anarchy. But, as Adam Watson (1997: 17) argues, too see the assumed anarchy as the cause of First World War is a gross oversimplification. It overlooks the fact that even though the European society of states had been for centuries "anarchic" in the technical sense of having no supranational authority, it was "for most of the time in fact adequately managed" (ibid.). To assume that the "anarchy" in the international system would be the same as anarchy within a political community is to lapse into domestic analogy, of which Hedley Bull (1966: 35) warned about: within a political 
community slipping into anarchy means the absence of authority, total chaos, disorder and havoc, but in the international sphere anarchy means solely the absence of greater authority than that of the sovereign states. Total chaos, lawlessness or disorder has not ensued from the absence of authority, and these terms have never charcterized the empirical international system. Domestic analogy is a misguided assumption that "the need of individual men to stand in awe of a common power in order to live in peace is a ground for holding that states must do the same" (Ibid.).

Yet, as a part of theory of international politics that would explain the logic of any states-system as neo-Realists like Waltz have it, international anarchy is nowhere to be found prior to the 1979 publication of Waltz's "Theory of International Politics" (Waltz, 1979) which takes it as the starting point of international relations. After Keohane's "Neorealism and Its Critics" (1986) anarchy has been the most central concept of the discipline, distinquishing it from politics within the state. Marting Wight is a curious exception. Despite his penchant for history and theory, he is not very meticulous in tracing the history of international anarchy. He assumes, like Dickinson, that the absence of international government and ensuing anarchy is the fundamental cause of wars (Wight, 1991: 101). According to him, "all particular causes of war operate within the context of international anarchy and the Hobbesian fear" and "[A]narchy is the chracteristic that distinguishes international politics from ordinary politics" (ibid.: 102). Wight is sloppy and does not show any convincing textual evidence that this would indeed be the assumption of the Realists. Also, when arguing in The Three Traditions that the sphere of international politics can be seen as either arena (Realists), international system (Rationalists) or world society (Revolutionists) he is destroying his own previous argument that international politics would take place in anarchic conditions. The anarchy of the international sphere is not incompatible with society.

Dickinson's depiction of international anarchy as deriving from Machiavelli and Hobbes has thereafter been the stereotypical image of it, but he was talking about his own particular historical context, not offering that term as explanatory for every states-system like Waltz (Donnelly, 2015: 398). It's emergence in the late 1970's and early 1980's has more to do with the debates within the discipline rather than any changes in the actual international system (Donnelly, 2015). One could ask why is there this obsession with international anarchy, as it is not really found in the classics nor was it central to early scholars working on world politics. Its effects are also derivative of the state sovereignty, which means that as an explanatory term international anarchy does not offer anything new to sovereignty. 


\section{References}

ARMITAGE, David, 2006. Hobbes and the Foundations of Modern International Thought. In Annabel Brett, James Tully and Holly Hamilton-Bleakley (eds.), Rethinking the Foundations of Modern Political Thought. Cambridge: Cambridge University Press, 219-235.

ASHLEY, Richard K., 1988. Untying the Sovereign State: A Double Reading of the Anarchy Problematique. Millennium, 17:2, 227-262.

BEDERMAN, David J., 2001. International Law in Antiquity. Cambridge: Cambridge University Press.

BEHR, Hartmut, 2010. A History of International Political Theory. Ontologies of the International. Houndmills: Palgrave Macmillan.

BELL, Duncan S. A., 2001. International Relations: the Dawn of a Historiographical Turn?. British Journal of Politics and International Relations, 3:1, 115-126.

BELL, Duncan S. A., 2002. Language, Legitimacy, and the Project of Critique. Alternatives, 27:3, 327-350.

BULL, Hedley, 1966. Society and Anarchy in International Relations. In Martin Wight and Herbert Butterfield (eds.), Diplomatic Investigations. London: G. Allen and Unwin, 35-50.

BULL, Hedley, 1977/2002. The Anarchical Society. A Study of Order in World Politics. New York: Columbia University Press.

BUZAN, Barry and Little, Richard, 1994. The Idea of "International System": Theory Meets History. International Political Science Review, 15:3, 231-255.

CHRISTOV, Theodore, 2015. Before Anarchy. Hobbes and His Critics in Modern International Thought. Cambridge: Cambridge University Press.

DICKINSON, G. Lowes, 1916. The European Anarchy. Available online at http:// www.gutenberg.org/ebooks/10333.

DICKINSON, G. Lowes, 1926/1937. The International Anarchy 1904-1914. London: George Allen \& Unwin.

DONNELLY, Jack, 2015. The Discourse of Anarchy in IR. International Theory, 7:3, 393-425.

EVRIGENIS, Ioannis D., 2014. Images of Anarchy. The Rhetoric and Science in Hobbes's State of Nature. Cambridge: Cambridge University Press.

FORDE, Steven, 1992. Varieties of Realism: Thucydides and Machiavelli. The Journal of Politics, 54:2, 372-393.

FREDERICK II of Prussia, 1740/1981. Anti-Machiavel. Columbus: Ohio University Press.

GARST, Timothy, 1989. Thucydides and Neorealism. International Studies Quarterly, 33, 3-27.

GEUNA, Marco, 2005. Machiavelli ed il ruolo dei conflitti nella vita politica. In Alessandro Arienzo and Dario Caruso (eds.), Conflitti. Naples: Libreria Dante \& Descartes, 19-57.

HENKIN, Louis, 1968. How Nations Behave. Law and Foreign Policy. New York: Praeger. 
HEXTER, J. H., 1957. Il Principe and lo stato. Studies in the Renaissance, 4, 113-138. HOBBES, Thomas, The English Works of Thomas Hobbes of Malmesbury (editions available online in Liberty Fund).

KEOHANE, Robert O. (ed.), 1986. Neorealism and Its Critics. New York: Columbia University Press.

KISSANE, Dylan, 2014. Beyond Anarchy. The Complex and Chaotic Dynamics of International Politics. Stuttgart: Ibidem Verlag.

KYLE, Donald G,. 1998. Spectacles of Death in Ancient Rome. London: Routledge.

LUKES, Timothy J., 2001. Lionizing Machiavelli. The American Political Science Review, 95:3, 561-575.

MACHIAVELLI, Niccolò, 1998. Tutte le opere storiche, politiche e letterarie. Ed. Alessandro Capata. Rome: Newton \& Compton.

MALCOLM, Noel, 2004. Aspects of Hobbes. Oxford: Clarendon Press.

MEIER, Christian and Ludz, Peter Christian, 1972. Anarchie, Anarchismus, Anarchist. In Otto Bruner, Werner Conze and Reinhart Koselleck (eds.), Geschichtliche Grundbegriffe. Historisches Lexikon zur Politisch-Sozialen Sprache in Deutschland. Stuttgart: Ernst Klett.

MEINECKE, Friedrich, 1924. Die Idee der Staatsräson in der neueren Geschichte. Munich: Oldenbourg.

MILNER, Helen, 1991. The Assumption of Anarchy in International Relations Theory: A Critique. Review of International Studies, 17, 67-85.

Morgenthau, Hans, 1948. Politics Among Nations. The Struggle for Power and Peace. New York: Alfred A. Knopf.

MÜLLERSON, Rein, 2000. Ordering Anarchy. International Law in International Society. The Hague: Martinus Nijhoff Publishers.

NOZICK, Robert, 1974. Anarchy, State and Utopia. New York: Basic Books.

NUSSBAUM, Arthur, 1958. A Concise History of The Law of Nations. New York: The MacMillan Company.

ONUF, Nicholas, 1991. Sovereignty: Outline of a Conceptual History. Alternatives, $16,425-446$.

QVILLER, Bjorn, 1996. The Machiavellian Cosmos. History of Political Thought, XVII:3, 326-353.

REINSCH, Paul, 1900. World Politics At the End of the Nineteenth Century as Influenced by the Oriental Situation. London: MacMillan.

SCHMIDT, Brian C., 1998. The Political Discourse of Anarchy: A Disciplinary History of International Relations. Albany: SUNY Press.

SCHUMAN, Frederick L., 1969. International Politics. Anarchy and Order in the World Society. New York: McGraw-Hill.

SKINNER, Quentin, 1988. A Reply to my Critics. In James Tully (ed.), Meaning \& Context: Quentin Skinner and his Critics. Cambridge: Polity Press, 231-288.

SPILLER, Gustav, 1916. International Law or International Anarchy. Advocate of Peace, December 1916, 339-340.

WALKER, R. B. J., 1993. Inside/Outside. International Relations as Political Theory. Cambridge: Cambridge University Press.

WALTZ, Kenneth N., 1979. Theory of International Politics. New York: Random House. 
Redescriptions 21/1

WATSON, Adam, 1997. The Limits of Independece. Relations Between States in The Modern World. London: Routledge.

WENDT, Alexander, 1992. Anarchy Is What States Make of It: The Social Construction of Power Politics. International Organization, 46:2, 391-425.

WIGHT, Martin, 1946/1978. Power Politics. Leicester:Leicester University Press.

WIGHT, Martin, 1966. Why is There No International Theory?. In Martin Wight and Herbert Butterfield (eds.), Diplomatic Investigations. London: G. Allen and Unwin, 17-34.

WIGHT, Martin, 1991. International Theory. The Three Traditions. Leicester and London: Leicester University Press.

WILLIAMS, Michael, 1996. Hobbes and International Relations: A Reconsideration. International Organization, 50:2, 213-236. 